\title{
Development of mix design for high strength Concrete with Admixtures
}

\author{
A.Annadurai ${ }^{1}$, A. Ravichandran ${ }^{2}$ \\ ${ }^{1}$ Department of Civil Engineering, Sathyabama University Chennai- 119 \\ ${ }^{2}$ Department of Civil Engineering Christ college of Engineering and Technology, Pondicherry.-605010
}

\begin{abstract}
This paper presents the result of mix design developed for high strength concrete with silica fume and High range water reducing admixture (HRWR). It involves the process of determining experimentally the most suitable concrete mixes in order to achieve the targeted mean strength. In this research work 53 grade ordinary Portland cement, the locally available river sand, $10 \mathrm{~mm}$ graded coarse aggregate were selected based on ASTM C 127 standard for determining the relative quantities and proportions for the grade of concrete M60. For this design ACI 211.4R-93 guidelines were followed. Totally Five mixes were designed one mix was treated as basic mix with HRWR - $0.5 \%$ without silica fume, Four mixes were designed with Micro silica quantities varied from 5 to 9 percent weight of cementitious materials and HRWR varies between $0.6 \%$ to $0.9 \%$ with increment of $0.1 \%$. Each mix 2 numbers of $150 \mathrm{~mm} \times 300 \mathrm{~mm}$ cylinders were cast then kept in curing tank after 24 hours of time period. After 28 days of curing the specimens were tested and the appropriate mix proportions were obtained.
\end{abstract}

Key word: High strength concrete,, Aggregates, Admixtures, ACI Mix Design, Compressive strength

\section{INTRODUCTION}

Although high-strength concrete is often considered a relatively new material, its development has been gradual over many years. As the development has continued, the definition of high-strength concrete has changed. In the1950s, concrete with a compressive strength of $34 \mathrm{~N} / \mathrm{mm}^{2}$ a was considered high strength. In the $1960 \mathrm{~s}$, concrete with and 41 and $52 \mathrm{~N} / \mathrm{mm}^{2}$ compressive strengths were used commercially. In the early 1970s, $62 \mathrm{~N} / \mathrm{mm}^{2}$ concrete was being produced. More recently, compressive strengths approaching $138 \mathrm{~N} / \mathrm{mm}^{2}$ have been used in cast-in-place buildings. For many years, concrete with compressive strength in excess of $41 \mathrm{~N} / \mathrm{mm}^{2}$ was available at only a few locations. However, in recent years, the applications of high-strength concrete have increased, and high-strength concrete has now been used in many parts of the world. The growth has been possible as a result of recent developments in material technology and a demand for higher-strength concrete The construction of Chicago's Water Tower Place and 311 South Wacker Drive concrete buildings would not have been possible without the development of high-strength concrete. The use of concrete superstructures in long span cable-stayed bridges such as East Huntington, W.V., and bridge over the Ohio River would not have taken place without the availability of high-strength concrete. . (ACI 363-R)

Realizing higher strength concrete has been a target or a dream for researchers and engineers engaged in construction industry. In the early 1960's, a super plasticizer was invented in Japan. By the inclusion of the super plasticizer, high-strength concrete could be realized by reducing W/C to fewer than $30 \%$. The highstrength concrete was however applied only to the factory products because it had a large loss in slump. Recent successful researches and developments on materials and construction methods have led to the cast-in place high-strength concrete with good workability, the strength of more than $150 \mathrm{~N} / \mathrm{mm}^{2}$ and higher durability. The high-strength concretes have been applied to a lot of high-rise buildings or diaphragm walls (Toru KAWAI). Two major remarkable developments of admixtures for high strength concrete are an invention of super plasticizer and a use of silica fume. Dr. Hattori developed formaldehyde condensates of beta-naphthalene sulfonates with the primary aim of significantly reducing the water demand of concrete to produce high-strength concrete. Water reductions of up to 30 percent were achieved with the use of this super plasticizer called Mighty 150. This admixture was introduced into the Japanese concrete industry as a nominal name of "high-range water-reducing admixture" in the early 1960's. Since then, it has considerably contributed to produce the highstrength concrete. In Germany, Dr. Aignesberger and his colleagues developed the melamine based super plasticizer having nearly the same performance as the beta-naphthalene based one. Silica fume is a by-product from the Ferro alloys industry. It consists of extremely fine amorphous silica particles. It must be always used to achieve the concrete with the strength of more than $80 \mathrm{~N} / \mathrm{mm}^{2}$. Replacement of the cement by silica fume increases the strength of the concrete and enhances the durability of the concrete. The reasons for this interesting property may be attributed to a micro filler effect and a pozzolanic reaction of silica fume in the cement 'based products. The particles of silica fume are a 100 times smaller than the cement grains. A mean diameter is approximately $0.1 \mu \mathrm{m}$. The micro filler effect means that silica fume particles are easily introduced into the space 
between cement grains, thus reducing the space available for water and producing dense structure of hydration products. The pozzolanic reaction means that silica fume particles react chemically with calcium hydroxide to produce well crystallized CSH gel and to enhance durability. (Toru KAWAI)

\section{Experimental work}

\subsection{Selection of materials for high strength concrete}

Ordinary Portland cement of 53 grade as per IS 12269- 1987 is used in the investigation. Crushed angular granite metal from a local source was used as coarse aggregate. The specific gravity is 2.74 . Fine aggregates with a rounded particle shape and smooth texture have been found to require less mixing water in concrete and for this reason are preferable in High strength concrete. High strength concrete typically contains such high contents of fine cementitious materials that the grading of the Fine aggregate used is relatively unimportant. However, it is sometimes helpful to increase the fineness modulus as the lower Fineness modulus of fine aggregate can give the concrete a sticky consistency (i.e. making concrete difficult to compact) and less workable fresh concrete with a greater water demand. Therefore, sand with a Fineness modulus of about 3.0 is usually preferred for HSC (ACI 363R, 1992). In this study fineness modulus of fine aggregate is calculated for many samples in that one sample were selected the fine aggregate having the fineness modulus value was 3.0. Concrete is being used for wide varieties of purposes to make it suitable in different conditions. In these conditions ordinary concrete may fail to exhibit the required quality performance or Durability. In such cases, admixture is used to modify the properties of ordinary concrete so as to make it more suitable for any situation. Reliable performance on previous work should be considered during the selection process. In this work hyper plasticizer GLENIUM B233, high range water reducing, Super plasticizer based on polycarboxylic ether formulation. The product specific gravity 1.08 \& solid contents not less than $30 \%$ by weight as per manufacturer data was used to maintain the workability of concrete and silica fume Densified - 920 D, with a typical bulk density of $500-700 \mathrm{~kg} / \mathrm{m}^{3}$ was used with replacement of cement as Pozzolanic or Mineral admixture.

\subsection{Mix Design}

In this study high strength concrete was designed based on ACI 211-4R 93 guidelines by using excel sheet. The reference table and the mix design calculations are given in appendix.

\subsection{Specimen details}

Totally five mix were designed in this one basic mix with High range water reducing admixture without silica fume, four trail mix proportions were arrived with variation of silica fume and High range water reducing admixture. Silica fume is replaced with cement in the range from $0 \%$ to $9 \%$ and the High range water reducing admixture is added into the mix in the range of 0.5 to $0.9 \%$. Each mix two $150 \times 300 \mathrm{~mm}$ cylinders were cast after checking the slump of the concrete. The specimens demoulded after 24 hours and kept curing for 28 days.

\subsection{Test results}

Specimens were tested to determine the characteristic compressive strength of high strength concrete as per ASTM C -39/C39M - 99 The cylinders were loaded in a 200T compression testing machine at the rate of 0.3 $\mathrm{N} / \mathrm{mm}^{2} / \mathrm{s}$ until failure as shown in Fig. 1. The results were tabulated as shown in Table No. 1, from the test results shows that the silica fume content increased, the compressive strength also increased gradually up to 9 percent silica fume replacement with cement content. The increased percentage of silica fume content demands more water and the slump value were also reduced. Fig. 2 shows the variation of silica fume content to compressive strength of concrete.

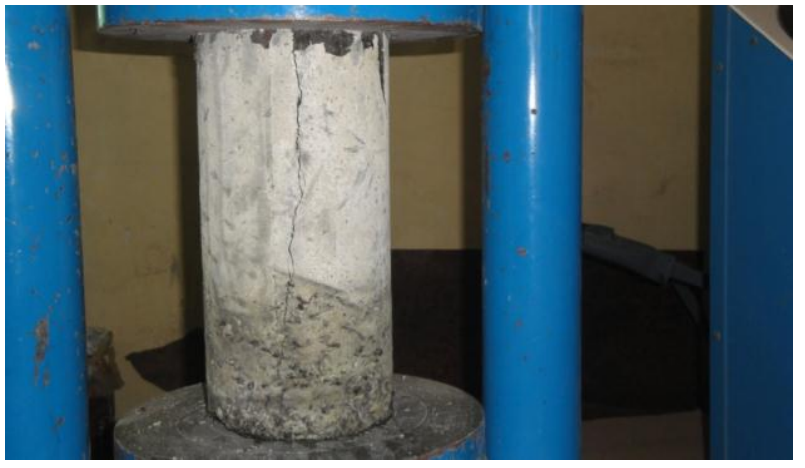

Fig .1 Compressive strength of cylinder load set up 
Table 1 Cylinder Compressive Strength of concrete for Various Mixes

\begin{tabular}{|l|l|l|l|l|l|l|l|}
\hline Trial Mix & $\begin{array}{l}\text { Cement } \\
\text { Kg. }\end{array}$ & $\begin{array}{l}\text { Silica } \\
\text { Fume } \\
\text { Kg. }\end{array}$ & $\begin{array}{l}\text { Fine } \\
\text { Aggregate } \\
\text { Kg. }\end{array}$ & $\begin{array}{l}\text { Coarse } \\
\text { Aggregate } \\
\text { Kg. }\end{array}$ & $\begin{array}{l}\text { HRWR } \\
\text { Kg. }\end{array}$ & $\begin{array}{l}\text { Water } \\
\text { Kg. }\end{array}$ & $\begin{array}{l}\text { 28days } \\
\text { compressive } \\
\text { strength } \\
\left(\mathbf{N} / \mathbf{m m}^{2}\right)\end{array}$ \\
\hline 1 & 512.00 & - & 594.40 & 1037.22 & 2.56 & 163.38 & 70.59 \\
\hline 2 & 481.28 & 30.72 & 594.40 & 1037.22 & 3.07 & 162.82 & 71.25 \\
\hline 3 & 476.16 & 35.84 & 594.40 & 1037.22 & 3.58 & 162.31 & 72.48 \\
\hline 4 & 471.04 & 40.96 & 594.40 & 1037.22 & 4.10 & 161.80 & 73.55 \\
\hline 5 & 465.92 & 46.08 & 594.40 & 1037.22 & 4.61 & 161.29 & 76.79 \\
\hline
\end{tabular}

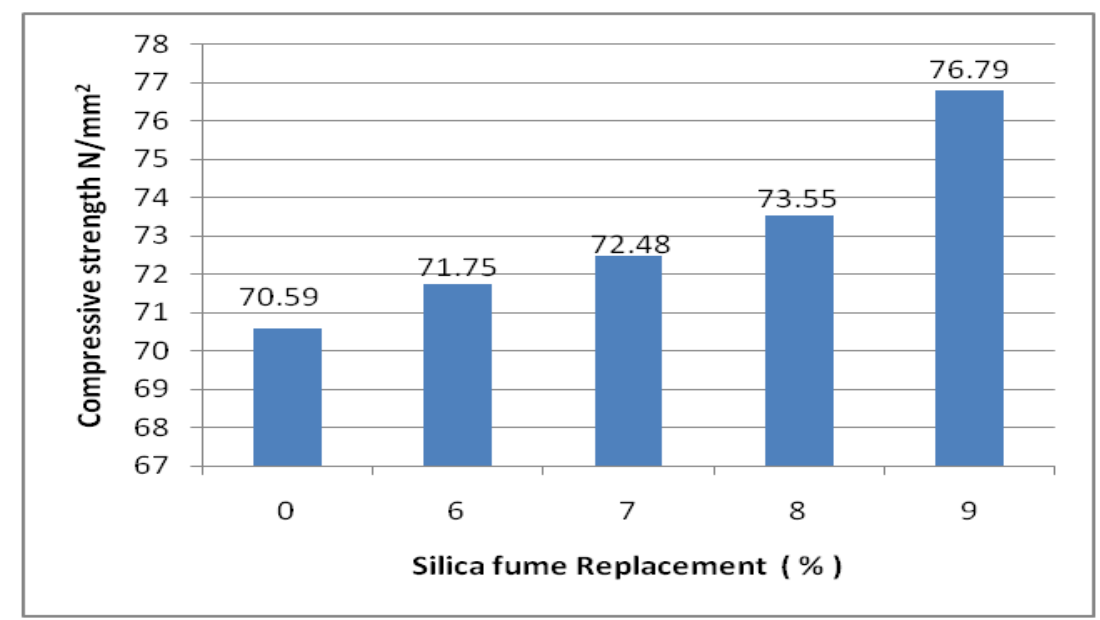

Fig. 2. Variation of Compressive Strength with Silica fume percentage

\section{Conclusion}

Based on the Investigation conducted on the Mix design of high strength concrete by using silica fume and High range water reducing admixture (HRWR), the following conclusions were made.

The fineness modulus of fine aggregate role is very important in the development of high strength concrete, in this study fineness modulus of fine aggregate were selected 3.0 by testing of various sample.

Increase in the percentage of Micro silica requires more demand of water because of the Greater fineness. To maintain the workability of the concrete use of super plasticizer is necessary.

Increase in Percentage of Micro silica the slump of the concrete was reduced, to maintain the require slump addition of super plasticizer is necessary.

In this study micro silica added from $0 \%$ to $9 \%$, the observation was Increase in micro silica compressive strength also increased up to $9 \%$ but the slump value was reduced.

Replacement of cement with Micro silica 9\%, HRWR $0.9 \%$ gave the maximum compressive strength.

\section{References}

[1] ACI. Committee. 211 (211 - 4R - 93.) "Guidelines for Selecting Proportions for High strength Concrete with Portland Cement and Fly Ash American concrete Institute, Detroit, Michigan,

[2] ACI committee 363R-92 (Reapproved 1997) State-of-the-Art Report on High-Strength Concrete

[3] ACI Committee 212 (212.4r -93) (reapproved 1996)" "Guide for the use of High - Range Water - Reducing Admixtures (Super plasticizers) in concrete". American concrete Institute

[4] ASTM C -39/C39m-99-standard test method for Compressive strength of cylindrical concrete specimens

[5] Toru KAWAI .St ate-of-the-art report on high-strength concrete - recent developments and applications in Japan

[6] Bhikshma. (2009 Investigations on mechanical properties of high strength silica fume concrete Asian journal of civil engineering (building and housing) vol. 10, no. 3 (2009) pages 335-346

[7] B.L.P Swami Studies on Cement Replacement in Concretes by Micro Silica 920-D, CI-Premier Private limited, Singapore concrete Institute.

[8] Mohammad Abdur Rashid: (2009) "Considerations in producing high strength concrete "journal of civil engineering (IEB) 37 (1) (2009) $53-63$.

[9] M. Yaqub "Development of mix design for high strength concrete" CI-Premier Private limited, Singapore concrete Institute.

[10] M.R. Taylor, (1996) F.D. "Mix proportions for high strength concrete "Construction and Building Material Vol. 10 NO.6, PP 445 450,1996

[11] Kwan Wai Hoe "Rational Mix Design Approach for High strength concrete Using Sand with very High Fineness Modulus" American Journal of Applied Sciences 7(12): 1562 -1568 , 2010. ISSN 1540 -9239 


\section{Appendix}

\section{ACI Mix Design}

A Data Collection:

\begin{tabular}{|c|c|c|c|c|c|c|}
\hline & & \multicolumn{3}{|c|}{ S.I units } & \multicolumn{2}{|l|}{ MKS } \\
\hline 1 & Specific Gravity of Cement & $:$ & 3.15 & & & \\
\hline 2 & Specific Gravity of Fine Aggregate & $:$ & 2.40 & & & \\
\hline 3 & Fineness modulus of Fine Aggregate & $:$ & 3.00 & & & \\
\hline 4 & Bulk Density of Fine Aggregate & : & 1643 & $\mathrm{Kg} / \mathrm{m}^{3}$ & 103 & $\mathrm{lb} / \mathrm{ft}^{3}$ \\
\hline 8 & Water absorption of Fine Aggregate & : & 0.45 & $\%$ & & \\
\hline 5 & Specific Gravity of Coarse Aggregate & $:$ & 2.74 & & & \\
\hline 6 & Fineness modulus of Coarse Aggregate & $:$ & 3.67 & & & \\
\hline 7 & Bulk Density of Coarse Aggregate & : & 1589 & $\mathrm{Kg} / \mathrm{m}^{3}$ & 99 & $\mathrm{lb} / \mathrm{ft}^{3}$ \\
\hline 8 & Water absorption of Coarse Aggregate & $:$ & 0.42 & $\%$ & & \\
\hline 9 & Slump & $:$ & $25-50$ & $\mathrm{~mm}$ & with HR & \\
\hline 10 & Specific Gravity of Silica Fume & : & 2.25 & & & \\
\hline
\end{tabular}

B Mean Design Strength:

\begin{tabular}{|c|cc|}
\multicolumn{1}{c}{$f_{\mathrm{cr}}$} \\
\hline fc- reqd. conc strength & \multicolumn{2}{c|}{ size of C.A } \\
\hline$<9000$ & $0.75-1.00$ \\
\hline$>9000$ & $0.75-0.50$ \\
\hline
\end{tabular}

C Select Optimum Coarse Aggregate Content:

Weight of coarse aggregate

\begin{tabular}{|c|c|c|c|c|}
\hline Nominal Sizeof C.A & 0.38 & 0.50 & 0.75 & 1.00 \\
\hline Frac. Vol. of ODRCA & 0.65 & 0.68 & 0.72 & 0.75 \\
\hline
\end{tabular}

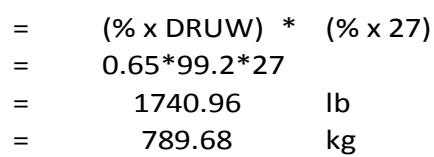

D Estimate the mixing water and air content:

\begin{tabular}{|c|c|c|c|c|}
\hline \multirow{3}{*}{ Slump, in } & \multicolumn{4}{|c|}{ Mixing Water } \\
\cline { 2 - 5 } & \multicolumn{4}{|c|}{ Maxize of C.A } \\
\cline { 2 - 5 } & 0.38 & 0.50 & 0.75 & 1.00 \\
\hline 1 to 2 & 310 & 295 & 285 & 280 \\
\hline 2 to 3 & 320 & 310 & 295 & 290 \\
\hline 3 to 4 & 330 & 320 & 305 & 300 \\
\hline $\begin{array}{l}\text { Entr. Air } \\
\text { Content }\end{array}$ & 3.00 & 2.50 & 2.00 & 1.50 \\
\cline { 2 - 5 } & 2.50 & 2.00 & 1.50 & 1.00 \\
\hline
\end{tabular}

Void Content\%$$
=
$$$$
=
$$

Mixing water adjustment

$=$$$
\begin{array}{lll}
= & -27.92 & \mathrm{lbs} / \mathrm{yd}^{3} \\
= & -16.47 & \mathrm{~kg} / \mathrm{m}^{3}
\end{array}
$$

The total mixing water required per yd3 of concrete is$$
(\mathrm{V}-35) * 8
$$$$
(31.51-35) * 8
$$

$(1-($ ODRUW/(Sp.Gr*62.4)) $) * 100$

$(1-(102.57 /(2.4 * 62.4))) * 100$

$31.51 \quad \%$

282.08 or $282.08 \mathrm{lb}$

This required mixing water includes the retarding admixture, but does not include water in HRWR. 
$E$ Select $w / c+P$ ratio:

Recommended max. $\mathrm{w} / \mathrm{c}+\mathrm{P}$ ratio for concrete made with HRWR

\begin{tabular}{|c|c|c|c|c|c|}
\hline \multirow{2}{*}{ Field Strength } & \multicolumn{4}{|c|}{$w / c+p$} \\
\cline { 3 - 6 } \multicolumn{2}{|c|}{} & \multicolumn{4}{|c|}{ Max size coarse aggregate } \\
\cline { 2 - 6 } 7000 & 0.38 & 0.50 & 0.75 & 1.00 \\
\cline { 2 - 6 } & 28 day & 0.50 & 0.48 & 0.45 & 0.43 \\
\hline \multirow{2}{*}{8000} & 28 day & 0.55 & 0.52 & 0.48 & 0.46 \\
\cline { 2 - 6 } & 56 day & 0.44 & 0.42 & 0.40 & 0.38 \\
\hline \multirow{2}{*}{9000} & 28 day & 0.38 & 0.45 & 0.42 & 0.40 \\
\cline { 2 - 6 } & 56 day & 0.42 & 0.39 & 0.35 & 0.34 \\
\hline \multirow{2}{*}{10000} & 28 day & 0.33 & 0.32 & 0.31 & 0.36 \\
\cline { 2 - 6 } & 56 day & 0.37 & 0.35 & 0.33 & 0.32 \\
\hline \multirow{2}{*}{11000} & 28 day & 0.30 & 0.29 & 0.27 & 0.27 \\
\cline { 2 - 6 } & 56 day & 0.33 & 0.31 & 0.29 & 0.29 \\
\hline \multirow{2}{*}{12000} & 28 day & 0.27 & 0.26 & 0.25 & 0.25 \\
\cline { 2 - 6 } & 56 day & 0.30 & 0.28 & 0.27 & 0.26 \\
\hline
\end{tabular}

\begin{tabular}{|c|c|c|c|c|c|c|}
\hline 10000 & - & 10102 & $=$ & 0.33 & - & $x$ \\
\hline 10000 & - & 11000 & $=$ & 0.33 & - & 0.30 \\
\hline
\end{tabular}

$$
w / c+p=0.327
$$

F Step and calculate content of cementitious material:

$\frac{282.08}{0.327}=863.00 \quad \mathrm{lb}$

The specifications do not set a minimum for cementitious material content, so $863 \quad \mathrm{lb} / \mathrm{yd}^{3} \quad$ of concrete will be used.

G Proportion basic mixture with cement only

1 Cement content per yd ${ }^{3}=863.00 \quad \mathrm{lb}$

2 The volumes per $\mathrm{yd}^{3}$ of all materials except sand are as follows:

\begin{tabular}{|c|c|c|c|c|c|}
\hline Cement & $=$ & $(863) /(3.15 * 62.4)$ & $=$ & 4.39 & $\mathrm{ft}^{3}$ \\
\hline Coarse Aggregate & $=$ & $(1740.96) /(2.74 * 62.4)$ & $=$ & 10.18 & $\mathrm{ft}^{3}$ \\
\hline Water & $=$ & $(282.08) /(62.4)$ & $=$ & 4.52 & $\mathrm{ft}^{3}$ \\
\hline Air & $=$ & $(0.02) *(27)$ & $=$ & 1.25 & $\mathrm{ft}^{3}$ \\
\hline \multicolumn{3}{|l|}{ Total Volume } & $=$ & 20.34 & $\mathrm{ft}^{3}$ \\
\hline
\end{tabular}

\begin{tabular}{|l|l|l|l|}
\hline Therefore, the required volume of sand per $\mathrm{yd} 3$ of concrete is $(27-20.34)=$ & 6.66 & $\mathrm{ft}^{3}$ \\
\hline
\end{tabular}

Converting this to weight of sand, per yd3 of concrete, the required weight of sand is

$$
(6.66) *(62.4) *(2.4) \quad=997.40 \quad \mathrm{lb}
$$


H Mix Design Ratio

\begin{tabular}{|c|c|c|c|c|c|}
\hline Cement & $=$ & 863.00 & $\mathrm{Ib}$ & 391.45 & $\mathrm{~kg}$ \\
\hline Sand & $=$ & 997.40 & $\mathrm{Ib}$ & 452.41 & $\mathrm{~kg}$ \\
\hline Coarse aggregate & $=$ & 1740.96 & $\mathrm{Ib}$ & 789.69 & $\mathrm{~kg}$ \\
\hline Water with HRWR & $=$ & 282.08 & $\mathrm{Ib}$ & 127.95 & $\mathrm{~kg}$ \\
\hline
\end{tabular}

I Adjustments:

\begin{tabular}{|l|l|l|l|l|l|l|l|}
\hline Cement & $=$ & 391.45 & $\mathrm{Kg}$ & 0.0000 & 391.45 & $\mathrm{Kg}$ & 1.00 \\
\hline Sand & $=$ & 452.41 & $\mathrm{Kg}$ & 0.0045 & 454.45 & $\mathrm{Kg}$ & 1.16 \\
\hline Coarse aggregate & $=$ & 789.69 & $\mathrm{Kg}$ & 0.0042 & 793.00 & $\mathrm{Kg}$ & 2.03 \\
\hline Water with HRWR & $=$ & 127.95 & $\mathrm{Kg}$ & 0.0087 & 126.84 & $\mathrm{Kg}$ & 0.32 \\
\end{tabular}

J For 1.0 Cu.M

\begin{tabular}{|l|l|c|c|l|}
\hline Cement & $=$ & 512.00 & $\mathrm{Kg}$ & 1.00 \\
\hline Sand & $=$ & 594.40 & $\mathrm{Kg}$ & 1.16 \\
\hline Coarse aggregate & $=$ & 1037.22 & $\mathrm{Kg}$ & 2.03 \\
\hline Water with HRWR & $=$ & 165.90 & $\mathrm{Kg}$ & 0.32
\end{tabular}

\begin{tabular}{|lc|c|}
\hline Companion mixture \#1 & 6 & Percent \\
\hline Companion mixture \#2 & 7 & Percent \\
\hline Companion mixture \#3 & 8 & Percent \\
\hline Companion mixture \#4 & 9.0 & Percent \\
\hline Companion mixture \#5 & 8.5 & Percent \\
\hline
\end{tabular}

\begin{tabular}{|c|c|c|c|c|}
\hline Companion mixture & Cement & Silica Fume & Total & Unit \\
\hline$\# 1$ & 481.28 & 30.72 & 512.00 & KG \\
\hline$\# 2$ & 476.16 & 35.84 & 512.00 & KG \\
\hline$\# 3$ & 471.04 & 40.96 & 512.00 & KG \\
\hline$\# 4$ & 465.92 & 46.08 & 512.00 & KG \\
\hline
\end{tabular}

\begin{tabular}{|ll|ll|}
\hline HRWR mixture \#1 & Companian Mixture \#1 & 0.60 & Percent \\
\hline HRWR mixture \#2 & Companian Mixture \#2 & 0.70 & Percent \\
\hline HRWR mixture \#3 & Companian Mixture \#3 & 0.80 & Percent \\
\hline HRWR mixture \#4 & Companian Mixture \#4 & 0.90 & Percent \\
\hline
\end{tabular}

K Usage of HRWR:

\begin{tabular}{|c|c|c|c|c|c|c|}
\hline Trial Mix & Cement & Silica Fumes & Fine Agg & Coarse Agg & HRWR & Water \\
\hline Comp \#1 & 481.28 & 30.72 & 594.40 & 1037.22 & 3.07 & 162.82 \\
\hline Comp \#2 & 476.16 & 35.84 & 594.40 & 1037.22 & 3.58 & 162.31 \\
\hline Comp \#3 & 471.04 & 40.96 & 594.40 & 1037.22 & 4.10 & 161.80 \\
\hline Comp \#4 & 465.92 & 46.08 & 594.40 & 1037.22 & 4.61 & 161.29 \\
\hline
\end{tabular}

